$\bigcirc$ 森田沙綾香(福井県立大) - 平舘俊太郎 · 藤井義晴(農環研) ・ 岸田真幸・ 原田二郎(福井県立大)

【目的】バイオアッセイの結果、バラ科シモツケ属のユキヤナギおよびシジミバナにおいて強い阻害活性が認め られたので本実験では、生態系におけるアレロパシーの可能性、ならびにその阻害活性物質の単離を目的として 行った。

\title{
【方法】
}

1. 葉のマルチがレタス苗の生育に及ぼす影響

$4 \mathrm{~L}$ の土（そ菜苗床土）を充填したプラスチクトレイを傾斜させ、サランネットで二分し、上部にユキャ ナギの生葉 $30 \mathrm{~g}$ 、下部にはレタス種子 $0.1 \mathrm{~g}$ （グレートレークス 366 号）を入れ、 1 日に 1 回上部に水を重点 的に加えた。50日後、平均的なレタス苗 15 個体を採取し、草丈、葉数、乾物重を測定した。 シジミバナも同様に行った。

\section{2. 切断葉からの阻害物質の影響}

底部にガラスウールを敷き詰めたロートにユキヤナギの葉 $20 \mathrm{~g}$ を入れ、 1 日 3 回霧吹きで蒸留水を噴霧し た。7 日後、ろ液に活性炭を $3 \mathrm{~g}$ いれて活性物質を吸着させ、アセトンで溶出、濃縮後、葉量 $0.1 、 0.5 、 1 、$ $2 \mathrm{~g}$ 相当量になるようメタノールで溶解し、バイオアッセイを行った。14 日、21 日後も同様に行った。また、 シジミバナについても同様に行った。

\section{3. 生葉による阻害物質の影響}

長さ約 $20 \mathrm{~cm}$ のシジミバナの枝付きの生葉に 1 日 5 回霧吹きで蒸留水を噴霧した。 3 日後、集めた噴霧水 に活性炭 $5 \mathrm{~g}$ を添加して活性物質を吸着させ、アセトンで溶出、濃縮した。葉 $0.003 、 0.01 、 0.03 、 0.1 、 0.3 \mathrm{~g}$ 相当量になるようメタノールで溶解し、バイオアッセイを行った。ユキヤナギについては葉 $0.01 、 0.03$ 、 $0.1 、 0.3 、 0.5 \mathrm{~g}$ 相当量で同様に行った。

\section{4. 阻害物質の単離}

ユキヤナギの葉より得た抽出液から、各種のクロマトグラフィーにより植物生育抑制物質を精製した (図 3)。

\section{【結果と考察】}

ユキヤナギ、シジミバナの葉のマルチでは、実験開始から約 30 日までは対照区に対して差は見受けられな かったが、40 日後になるとわずかであるが差が見られた。50日後、検定植物の草丈、葉数、乾物重を測定し た結果(図 1)、明らかに各植物のマルチによる影響を受けていることが明らかとなった。そこで、ユキャナギ、

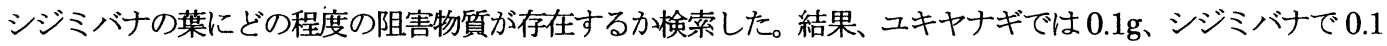

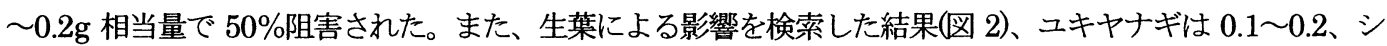
ジミバナでは $0.06 \sim 0.1 \mathrm{~g}$ 相当量で $50 \%$ 阻害された。以上の結果からユキヤナギ、シジミバナの葉にはレタス 苗の生育を阻害する他感作用を示す阻害物質があることが明らかとなった。

また、その阻害物質を検索するために溶媒抽出を行った。バイオアッセイの結果、酢酸エチル画分と水画分 に阻害活性が二分された。そこで、HPLCなどの精製方法を用いて各画分を精製・単離した。

現在、NMR 分析機器を用いてユキヤナギの葉が示す阻害物の構造を検討中である。また、シジミバナにつ いては、活性成分の精製・単離を行っている。 

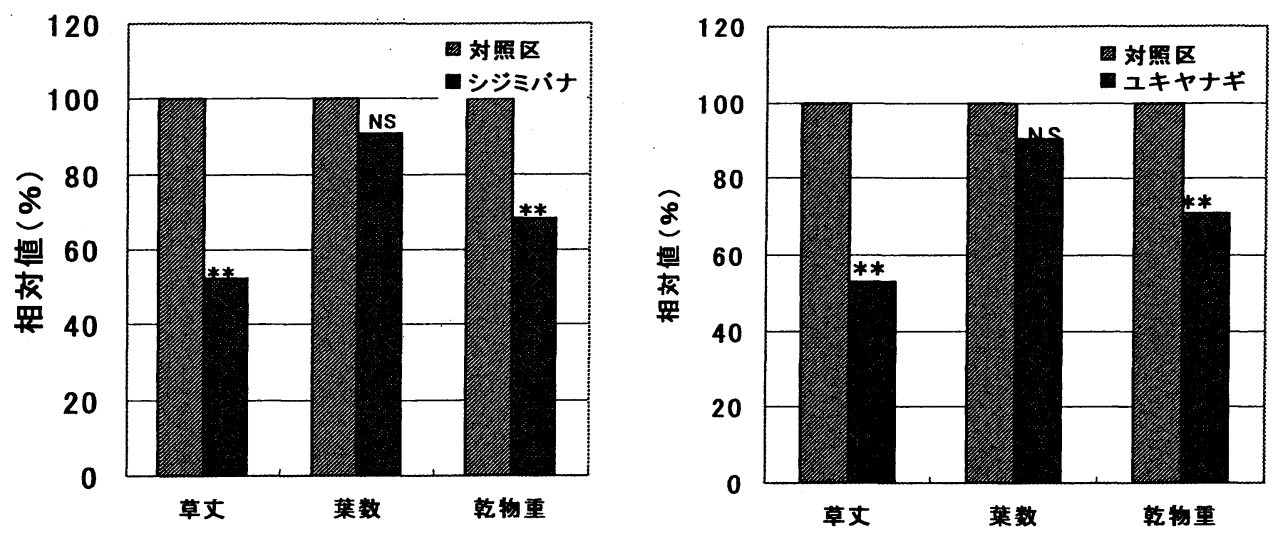

図1葉のマルチがレタス苗の生育に及ぼす影響
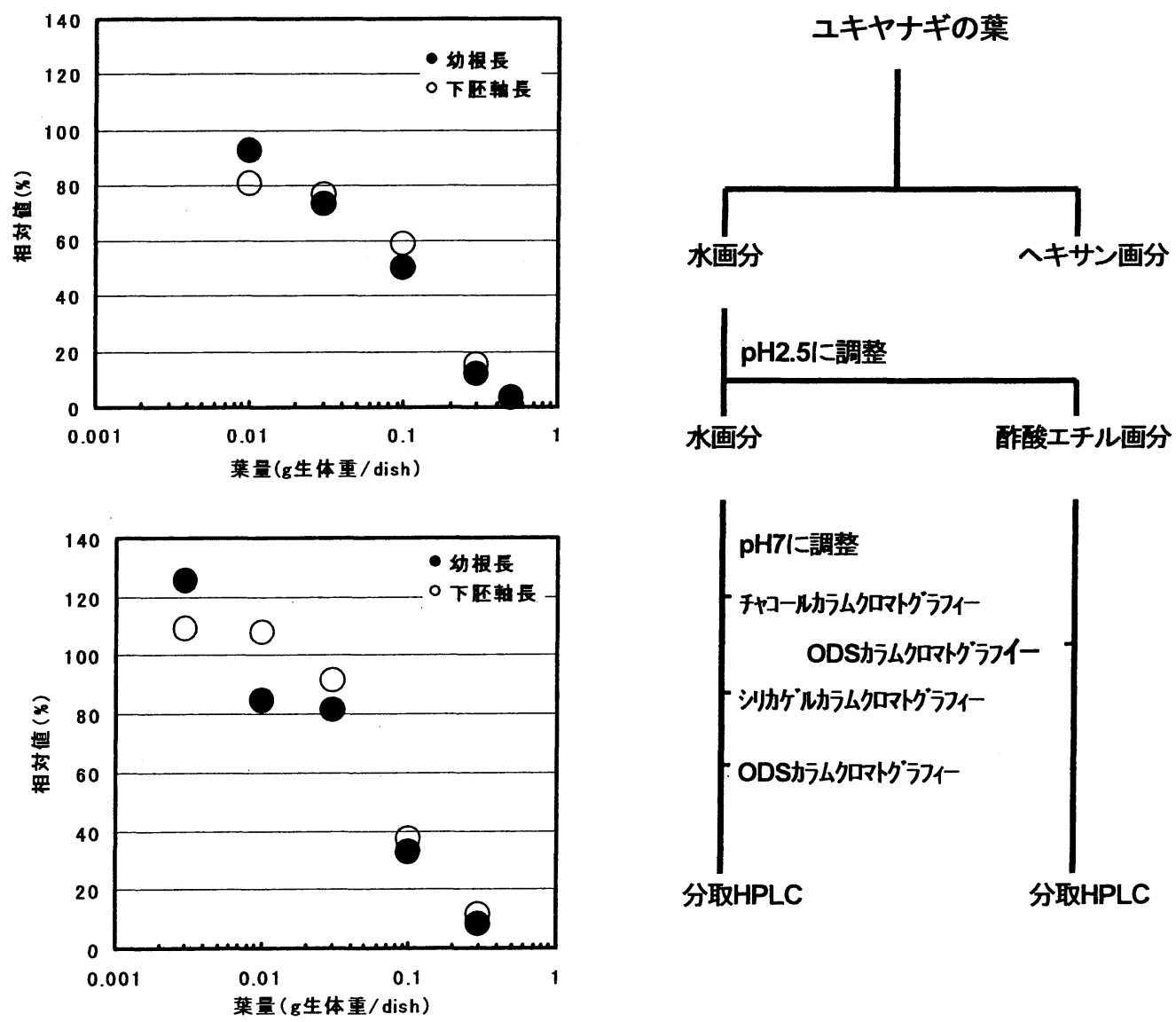

図2 生葉による阻害物質の影響

上:シジミバナ 下:ユキヤナギ

図 3 植物生長阻害物質の分画法 